\title{
Effect of Plant Growth Regulators on Partially Aged Seeds of Spinach (Spinacea oleracea L.) Genotypes
}

\author{
Satya Prakash ${ }^{1 *}$, Poonam Singh ${ }^{4}$, Kunwar A.P. Singh², Vipul Singh ${ }^{3}$, \\ Raghvendra Singh ${ }^{3}$, S.C. Vimal ${ }^{1}$ and Sagar Kumar Sharma ${ }^{4}$ \\ ${ }^{1}$ Department of Seed Science and Technology, ${ }^{2}$ Department of Horticulture, \\ ${ }^{3}$ Department of Agronomy, N. D. U. A. \& T., Faizabad, India \\ ${ }^{4}$ Department of Seed Science and Technology, C. S. A. U. A. \& T., Kanpur, India \\ *Corresponding author
}

\begin{tabular}{|c|c|}
\hline \multicolumn{2}{|r|}{ A B S T R A C T } \\
\hline & \multirow{7}{*}{$\begin{array}{l}\text { Spinach is a good source of vitamins riboflavin and calcium and dietary fiber. Now a day } \\
\text { plant growth regulators are playing a very important role in increasing yield, growth and } \\
\text { improving the quality of crops. The experiment comprised seed treatments of plant growth } \\
\text { regulators viz., Gibberllic Acid }\left(\mathrm{GA}_{3}\right) \text {, Indole Acetic Acide (IAA), 2,3,5 Trido Benzoic } \\
\text { Acid (TIBA) the observations were recorded on characters viz., germination }(\%) \text {, abnormal } \\
\text { seedling }(\%) \text {, shoot length }(\mathrm{cm}) \text {, root length }(\mathrm{cm}) \text {, seedling length }(\mathrm{cm}) \text {, seedling dry } \\
\text { weight }(\mathrm{g}) \text { and seedling vigour index-I. The study revealed that the different PGRs effects } \\
\text { significant for all parameters. The application growth regulators } \mathrm{GA}_{3} @ 50 \mathrm{ppm} \text { improved } \\
\text { root length }(7.37 \mathrm{~cm}) \text {, shoot length }(7.91 \mathrm{~cm}) \text {, seedling length }(15.28 \mathrm{~cm}) \text { and seedling } \\
\text { vigour index }-1(976.81) \text {. While, the application of GA } \mathrm{G}_{3} @ 100 \mathrm{ppm} \text { recorded maximum } \\
\text { germination }(64.72 \%) \text { and dry weight }(0.570 \mathrm{~g}) \text {. Among varieties, variety Allgreen was } \\
\text { found superior for improved root length, shoot length, seedling length and seedling vigour } \\
\text { index -1. It may be concluded that germination, seedling growth and vigour of partially } \\
\text { aged seed of spinach can be significantly improve with the Application of } \mathrm{GA}_{3} @ 50 \text { ppm } \\
\text { on variety Allgreen. }\end{array}$} \\
\hline Keywords & \\
\hline $\begin{array}{l}\text { Spinach, Seed } \\
\text { parameters, Plant } \\
\text { growth regulators. }\end{array}$ & \\
\hline Article Info & \\
\hline $\begin{array}{l}\text { Accepted: } \\
\text { 12 September } 2017\end{array}$ & \\
\hline Available Online: & \\
\hline & \\
\hline
\end{tabular}

\section{Introduction}

Spinach (Spinacia oleracea) is an edible flowering plant in the family Amaranthaceae. It is native to central and south western Asia. It is an annual plant (rarely biennial) which grows to a height upto $30 \mathrm{~cm}$. Spinach may survive over winter in temperate regions. The leaves are alternate, simple with ovate to triangular, variable in size from about $2-30 \mathrm{~cm}$ long and $1-15 \mathrm{~cm}$ broad with larger leaves at the base of the plant and smaller leaves higher on the flowering stem. The flowers are inconspicuous, yellow -green, 3-4 $\mathrm{mm}$ diameter, maturing into a small, hard, dry, lumpy fruit cluster of $5-10 \mathrm{~mm}$ across containing several seeds. Common spinach / palak were long considered to be in the family chenopodiaceae, but in 2003, that family was merged into the family amaranthaceae in the order caryophyllales. Within the family amaranthaceae, amaranthoideae and chenopodioideae are now subfamilies for the amaranths and the chenopods, respectively.

Spinach is thought to have originated in ancient Persia (modern Iran and neighboring 
countries). It is not known by whom and when spinach was introduced to India but the plant was subsequently introduced to ancient china where it was known as "Persian vegetable. Now a day plant growth regulators are playing a very important role in increasing yield, growth and improving the quality of crops. It is now recognized that vital physiological activities of the plants are regulated by the chemical, substances called "hormones".

The presence of growth regulating hormones in plants was first suggested by "Julius von sach" In the latter half of the $19^{\text {th }}$ century he proposed that these were "organ forming substances" in plant which were produced in the leaves and translocated downward in the plant.

Intensive work on plant growth regulators and gibberellins was started in India under the "All India Coordinated Schemes (1956-1963) of the ICAR to study the effect of application of growth regulating substances in horticulture, with two centers at Patiala and Kodur (A.P.).

Gibberellins present in various stages of growth, The GA regulates plant part and various stage of growth). It involves in cell division and cell enlargement. In the early stage of seed germination, GA may be present and this hormone is certainly involved in the regulation of some growth processes in young seedlings. In stems, GA is of general occurrence and its important role in regulations of growth is well known. GA may be found in roots and leaves but a regulatory role over the growth of roots or leaves seems doubtful. $\mathrm{GA}_{3}$, IAA and NAA are important constituents of plant, which rodox system plays an important role in increasing yield of mature plants as well as germination and growth of plants. Soaking of seed with these growth regulators accelerates the metabolic process involved in seed germination and improves growth and yield of plants. Auxin have tendency to accelerate cell division and cell elongation. In this way these growth regulators increase the plant height and accelerate the growth of the plant.

Seed germination and seedling growth phase of plants are critical for determining the crop stand density and establishment under different conditions. Seed germination in a laboratory test, is the emergence and development from the seed embryo of those essential structures which, for the kind of seed being tested, indicate the ability to develop into a normal plant under favourable conditions in the soil. Utility of hormonal research in India has been well recognised. Quite good amount of literature is available on its use and beneficial effects in field crops but very limited work has been done on vegetable crops. Since the yield is directly related to plant stand and vigour of the seedling and these attributes depend on the germination percentage and root, shoot length, dry weight seedling, etc.

\section{Materials and Methods}

The experiment was conducted on one year old partially aged spinach genotypes "Allgreen and Kantedar" having germination below IMSCS (60\%). The experiment was conducted under laboratory condition of the Department of Seed Science and Technology, C.S. Azad University of Agriculture and Technology, Kanpur (U.P.). The following methods were adopted for successful experimentation.

For the preparation of solution of the growth regulators $1 \mathrm{~g}$ of each chemical was taken in an individual neat and clean beaker. These chemicals were dissolved separately in a few drops of alcohol. This alcoholic solution was added in $500 \mathrm{ml}$ of distilled water with constant stirring. The volume of solution was 
finally constituted to one liter. This was the 1000 ppm stock solution of each chemical.

The flasks containing chemicals were covered with muslin cloth to avoid any contamination and deterioration in the chemical properties of the growth regulators. For preparation of 50 and $100 \mathrm{ppm}$ solution of each growth regulator 50 and $100 \mathrm{ml}$ of solution from the stock solution was taken in a well cleaned measuring flask and water is added to constitute to $1000 \mathrm{ml}$.

After preparation of solution, seed of both the variety viz., Allgreen and Kantedar were soaked in desired solution for 12 hours at 20 $25^{\circ} \mathrm{C}$ temperature. Simultaneously, seeds were also soaked in distilled water; for $12 \mathrm{hrs}$ as control. After prescribed period of soaking, solution was drained out from the beaker and soaked seeds were air dried and then placed for germination in controlled laboratory conditions. The observations were recorded on seed parameters viz., standard germination in percent, shoot length in centimeter, abnormal seedling, (\%), root length in centimeter, seedling length in centimeter, seedling dry weight in gram and seedling vigour index (SVI) -1 .

The analysis of data was done following the factorial Completely Randomized Design. The steps employed are given below. The various statistical techniques were used for calculation of the data as suggested by Cochran and Cox (1957).

\section{Results and Discussion}

Plant growth regulators viz. $\mathrm{GA}_{3}$, IAA, TIBA, play an important role in seed germination, seedling growth, vegetative growth and yield in most of crops. The application of growth regulators like Gibberellins, IAA, and TIBA etc. may prove helpful in increasing production of vegetables. Soaking of seed with these growth regulators accelerated the metabolic process involved during seed germination, seedlings growth and also improves growth and yield (Thapa et al., 2013 and Vijendra Kumar et al., 2014).

Among different plant growth regulators, AUXIN is primarily a single naturally occurring substance to be identified as Indole Acetic Acid (IAA). It is involved in cell wall synthesis, xylem differentiation, cell division, cell elongation, photosynthesis, apical dominance, root and shoot growth, prevention of abscission layer, respiration and also increase the certain enzymes.

Similarly, Gibberellins are involved in seed germination, mobilization of foods in seed storage cell, cell elongation and permeability of cell membrane, apical bud dormancy, role in sub- apical meristem, flowering and fruit growth. Beside these, Gibberellins induce synthesis of hydrolytic enzymes.

Seed germination and seedling growth phase of plants are critical for determining the crop stand density and establishment under different condition. Seed germination in a laboratory test, is the emergence and development from the seed embryo of those essential structure which, for the kind of seed being tested, indicate the ability to develop into a normal plant under favorable conditions in the soil. Since, the yield is directly related to plant stand and vigour of the seedling and these attribute depend on the germination percentage and root, shoot length, dry weight seedling etc. The present investigation was, therefore, planned to study the effect and use of plant growth regulators in enhancing the germination and vigour of aged palak (Spinach) seed, because its seeds having hard seed covering with multigerms and face the problem in germination. In this experimentation, partially aged seeds of two genotypes of spinach i.e., Kantedar and 
Allgreen were taken and seeds were soaked for 12 hours in solution of 50 and $100 \mathrm{ppm}$ concentration of $\mathrm{GA}_{3}$, IAA and TIBA to improve the seed germination and other quality parameters viz., normal seedling, abnormal seedling, shoot, root and seedling length, seedling dry weight and vigour index 1.

It was revealed by the statistical analysis of data that significant effect of variety was found for all the parameter except abnormal seedling shoot length, seedling length and seedling vigour-1 whereas effect of treatment and interaction of variety $\times$ treatment $(\mathrm{V} \times \mathrm{T})$ were found significant for all parameters.

Effects of variety on seed germination, seedling growth and vigour

Significantly maximum germination $(62.78 \%)$ was found in variety Kantedar but for other parameter like root length $(6.62 \mathrm{~cm})$, seedling dry weight $(0.500 \mathrm{~g})$ significantly higher valves were found in variety Allgreen than variety Kantedar. Numerically higher values for shoot length $(6.77 \mathrm{~cm})$, seedling length $(13.29 \mathrm{~cm}) \mathrm{SV}-1(828.58)$ were also exhibited by variety Allgreen. Significant effect of varieties was also reported by Singh et al., (2004) in Soybean and Okra.
Effect of treatment on seed germination, seedling growth and vigour

Significantly maximum germination in terms of normal seedlings were found when seeds were treated by $\mathrm{GA}_{3} 100$ ppm (64.72\%), IAA 100 ppm (64.02\%) and $\mathrm{GA}_{3} 50$ ppm (63.91\%) and found percent improvement of 17.22, 15.95 , and 15.75 in germination over control $(55.21 \%)$, respectively (Table 1$)$. The percent of abnormal seedlings were reduced significantly when seeds were treated with $\mathrm{GA}_{3} 100$ ppm (20.03), GA 50 ppm (20.43) IAA $100 \mathrm{ppm}$ (20.62) and IAA $50 \mathrm{ppm}$ (20.89) when the control showed 29.79 and $\mathrm{GA}_{3}$ they showed that $32.76,31.41,30.78$ and $26.51 \%$ decrease in number of abnormal seedlings over control, respectively (Table 2). Similar results were obtained by findings of Natesh et al., (2005) in Chilli, Singh et al., (2006) in Okra, Bateshwar et al., (2008) in Okra, Hilli et al., (2008) in ridge gourd, Nirmala et al., (2008) in beet root, Patil et al., (2008) in Okra, Nagre et al., (2008) in Indian spinach, Patil and Patel (2010) in okra, Nabi et al., (2010) in okra, Rouhi et al., (2011) in soybean, Thapa et al., (2013) in sprouting broccoli, Xu hui chun et al., (2013) in water melon, Mahipat et al., (2013) in mung bean, Vijendra Kumar et al., (2014) in garden rue and Li Weifei (2014) in Robinia pseudoacacia.

Table.1 Effect of different growth regulators and their concentrations on standard germination (\%) (normal seedlings) of spinach genotypes

\begin{tabular}{|c|l|c|c|c|}
\hline S.No. & \multicolumn{1}{|c|}{ Treatments } & Kantedar $\left(\mathbf{V}_{\mathbf{1}}\right)$ & Allgreen $\left(\mathbf{V}_{\mathbf{2}}\right)$ & Mean \\
\hline $\mathbf{1 .}$ & Control $\left(\mathrm{T}_{0}\right)$ & 53.01 & 57.42 & 55.21 \\
\hline $\mathbf{2 .}$ & $\mathrm{GA}_{3} 50 \mathrm{ppm}\left(\mathrm{T}_{1}\right)$ & 64.75 & 63.08 & 63.91 \\
\hline $\mathbf{3 .}$ & $\mathrm{GA}_{3} 100 \mathrm{ppm}\left(\mathrm{T}_{2}\right)$ & 65.88 & 63.56 & 64.72 \\
\hline $\mathbf{4 .}$ & IAA 50 ppm $\left(\mathrm{T}_{3}\right)$ & 62.85 & 64.25 & 63.55 \\
\hline $\mathbf{5 .}$ & IAA $100 \mathrm{ppm}\left(\mathrm{T}_{4}\right)$ & 64.25 & 63.79 & 64.02 \\
\hline $\mathbf{6 .}$ & TIBA 50 ppm $\left(\mathrm{T}_{5}\right)$ & 64.25 & 60.75 & 62.50 \\
\hline $\mathbf{7 .}$ & TIBA 100 ppm $\left(\mathrm{T}_{6}\right)$ & 64.52 & 62.55 & 63.53 \\
\hline & Mean & 62.78 & 62.20 & \\
\hline & & Variety & Treatments & V x T \\
\hline & SE $(\mathrm{D})$ & 0.23 & 0.43 & 0.61 \\
\hline & CD $(\mathrm{P}=0.05)$ & 0.47 & 0.88 & 1.24 \\
\hline
\end{tabular}


Table.2 Effect of different growth regulators and their concentrations on abnormal seedling $(\%)$ of spinach

\begin{tabular}{|c|l|c|c|c|}
\hline S.No. & \multicolumn{1}{|c|}{ Treatments } & Kantedar $\left(\mathbf{V}_{\mathbf{1}}\right)$ & Allgreen $\left(\mathbf{V}_{\mathbf{2}}\right)$ & Mean \\
\hline $\mathbf{1 .}$ & Control $\left(\mathrm{T}_{0}\right)$ & 31.95 & 27.63 & 29.79 \\
\hline $\mathbf{2 .}$ & $\mathrm{GA}_{3} 50 \mathrm{ppm}\left(\mathrm{T}_{1}\right)$ & 20.07 & 20.79 & 20.43 \\
\hline $\mathbf{3 .}$ & $\mathrm{GA}_{3} 100 \mathrm{ppm}\left(\mathrm{T}_{2}\right)$ & 19.27 & 20.79 & 20.03 \\
\hline $\mathbf{4 .}$ & IAA $50 \mathrm{ppm}\left(\mathrm{T}_{3}\right)$ & 21.97 & 20.82 & 21.89 \\
\hline $\mathbf{5 .}$ & IAA 100 ppm $\left(\mathrm{T}_{4}\right)$ & 20.27 & 20.97 & 20.62 \\
\hline $\mathbf{6 .}$ & TIBA 50 ppm $\left(\mathrm{T}_{5}\right)$ & 22.20 & 22.79 & 22.49 \\
\hline $\mathbf{7 .}$ & TIBA 100 ppm $\left(\mathrm{T}_{6}\right)$ & 21.27 & 22.36 & 21.81 \\
\hline & Mean & 22.42 & 22.45 & \\
\hline & & Variety & Treatments & V x T \\
\hline & SE $(\mathrm{D})$ & 0.23 & 0.4 & 0.61 \\
\hline & CD $(\mathrm{P}=0.05)$ & N.S. & 0.87 & 1.23 \\
\hline
\end{tabular}

Table.3 Effect of different growth regulators and their concentrations on shoot length $(\mathrm{cm})$ of spinach

\begin{tabular}{|l|l|c|c|c|}
\hline S.No. & \multicolumn{1}{|c|}{ Treatments } & Kantedar $\left(\mathbf{V}_{\mathbf{1}}\right)$ & Allgreen $\left(\mathbf{V}_{\mathbf{2}}\right)$ & Mean \\
\hline $\mathbf{1 .}$ & Control $\left(\mathrm{T}_{0}\right)$ & 6.75 & 7.00 & 6.87 \\
\hline $\mathbf{2 .}$ & $\mathrm{GA}_{3} 50 \mathrm{ppm}\left(\mathrm{T}_{1}\right)$ & 7.99 & 7.83 & 7.91 \\
\hline $\mathbf{3 .}$ & $\mathrm{GA}_{3} 100 \mathrm{ppm}\left(\mathrm{T}_{2}\right)$ & 7.49 & 7.65 & 7.57 \\
\hline $\mathbf{4 .}$ & IAA 50 ppm $\left(\mathrm{T}_{3}\right)$ & 7.09 & 7.64 & 7.36 \\
\hline $\mathbf{5 .}$ & IAA 100 ppm $\left(\mathrm{T}_{4}\right)$ & 6.25 & 7.73 & 6.99 \\
\hline $\mathbf{6 .}$ & TIBA 50 ppm $\left(\mathrm{T}_{5}\right)$ & 3.89 & 5.01 & 4.45 \\
\hline $\mathbf{7 .}$ & TIBA 100 ppm $\left(\mathrm{T}_{6}\right)$ & 7.11 & 4.59 & 5.85 \\
\hline & Mean & 6.65 & 6.77 & \\
\hline & & Variety & Treatments & V x T \\
\hline & SE $(\mathrm{D})$ & 0.07 & 0.13 & 0.19 \\
\hline & CD $(\mathrm{P}=0.05)$ & N.S. & 0.27 & 0.38 \\
\hline
\end{tabular}

Table.4 Effect of different growth regulators and their concentrations on root length $(\mathrm{cm})$ of spinach

\begin{tabular}{|l|l|c|c|c|}
\hline S.No. & \multicolumn{1}{|c|}{ Treatments } & Kantedar $\left(\mathbf{V}_{\mathbf{1}}\right)$ & Allgreen $\left(\mathbf{V}_{\mathbf{2}}\right)$ & Mean \\
\hline $\mathbf{1 .}$ & Control $\left(\mathrm{T}_{0}\right)$ & 5.52 & 6.00 & 5.76 \\
\hline $\mathbf{2 .}$ & $\mathrm{GA}_{3} 50 \mathrm{ppm}\left(\mathrm{T}_{1}\right)$ & 7.15 & 7.60 & 7.37 \\
\hline $\mathbf{3 .}$ & $\mathrm{GA}_{3} 100 \mathrm{ppm}\left(\mathrm{T}_{2}\right)$ & 6.38 & 8.33 & 7.35 \\
\hline $\mathbf{4 .}$ & IAA 50 ppm $\left(\mathrm{T}_{3}\right)$ & 6.33 & 6.24 & 6.28 \\
\hline $\mathbf{5 .}$ & IAA 100 ppm $\left(\mathrm{T}_{4}\right)$ & 6.15 & 7.94 & 7.04 \\
\hline $\mathbf{6 .}$ & TIBA 50 ppm $\left(\mathrm{T}_{5}\right)$ & 4.66 & 5.46 & 5.06 \\
\hline $\mathbf{7 .}$ & TIBA 100 ppm $\left(\mathrm{T}_{6}\right)$ & 5.50 & 4.82 & 5.16 \\
\hline & Mean & 5.95 & 6.62 & \\
\hline & & Variety & Treatments & V $\mathbf{~ T}$ \\
\hline & SE $(\mathrm{D})$ & 0.08 & 0.16 & 0.23 \\
\hline & CD $(\mathrm{P}=0.05)$ & 0.17 & 0.33 & 0.47 \\
\hline
\end{tabular}


Table.5 Effect of different growth regulators and their concentrations on seedling length $(\mathrm{cm})$ of spinach

\begin{tabular}{|l|l|c|c|c|}
\hline S.No. & \multicolumn{1}{|c|}{ Treatments } & Kantedar $\left(\mathbf{V}_{\mathbf{1}}\right)$ & Allgreen $\left(\mathbf{V}_{\mathbf{2}}\right)$ & Mean \\
\hline $\mathbf{1 .}$ & Control $\left(\mathrm{T}_{0}\right)$ & 12.27 & 13.00 & 12.63 \\
\hline $\mathbf{2 .}$ & $\mathrm{GA}_{3} 50 \mathrm{ppm}\left(\mathrm{T}_{1}\right)$ & 15.14 & 15.43 & 15.28 \\
\hline $\mathbf{3 .}$ & $\mathrm{GA}_{3} 100 \mathrm{ppm}\left(\mathrm{T}_{2}\right)$ & 13.87 & 15.98 & 14.92 \\
\hline $\mathbf{4 .}$ & IAA 50 ppm $\left(\mathrm{T}_{3}\right)$ & 13.42 & 13.08 & 13.25 \\
\hline $\mathbf{5 .}$ & IAA 100 ppm $\left(\mathrm{T}_{4}\right)$ & 12.40 & 15.67 & 14.03 \\
\hline $\mathbf{6 .}$ & TIBA 50 ppm $\left(\mathrm{T}_{5}\right)$ & 8.55 & 10.47 & 9.51 \\
\hline $\mathbf{7 .}$ & TIBA 100 ppm $\left(\mathrm{T}_{6}\right)$ & 12.61 & 9.41 & 11.01 \\
\hline & Mean & 12.60 & 13.29 & \\
\hline & & Variety & Treatments & V x T \\
\hline & SE $(\mathrm{D})$ & 0.12 & 0.23 & 0.33 \\
\hline & CD $(\mathrm{P}=0.05)$ & N.S. & 0.47 & 0.67 \\
\hline
\end{tabular}

Table.6 Effect of different growth regulators and their concentrations on seedling dry weight (g) of spinach genotypes

\begin{tabular}{|l|l|c|c|c|}
\hline S.No. & \multicolumn{1}{|c|}{ Treatments } & Kantedar $\left(\mathbf{V}_{\mathbf{1}}\right)$ & Allgreen $\left(\mathbf{V}_{\mathbf{2}}\right)$ & Mean \\
\hline 1. & Control $\left(\mathrm{T}_{0}\right)$ & 0.510 & 0.500 & 0.500 \\
\hline $\mathbf{2 .}$ & $\mathrm{GA}_{3} 50 \mathrm{ppm}\left(\mathrm{T}_{1}\right)$ & 0.540 & 0.520 & 0.530 \\
\hline $\mathbf{3 .}$ & $\mathrm{GA}_{3} 100 \mathrm{ppm}\left(\mathrm{T}_{2}\right)$ & 0.570 & 0.580 & 0.570 \\
\hline $\mathbf{4 .}$ & $\mathrm{IAA} 50 \mathrm{ppm}\left(\mathrm{T}_{3}\right)$ & 0.470 & 0.510 & 0.490 \\
\hline $\mathbf{5 .}$ & IAA 100 ppm $\left(\mathrm{T}_{4}\right)$ & 0.500 & 0.540 & 0.520 \\
\hline $\mathbf{6 .}$ & TIBA 50 ppm $\left(\mathrm{T}_{5}\right)$ & 0.410 & 0.430 & 0.420 \\
\hline $\mathbf{7 .}$ & TIBA 100 ppm $\left(\mathrm{T}_{6}\right)$ & 0.440 & 0.420 & 0.430 \\
\hline & Mean & 0.490 & 0.500 & \\
\hline & & Variety & Treatments & V x T \\
\hline & $\mathrm{SE}(\mathrm{D})$ & 0.004 & 0.008 & 0.011 \\
\hline & $\mathrm{CD}(\mathrm{P}=0.05)$ & 0.008 & 0.016 & 0.022 \\
\hline
\end{tabular}

Table.7 Effect of different growth regulators and their concentrations on seed vigour-I of spinach genotypes

\begin{tabular}{|l|l|c|c|c|}
\hline S.No. & \multicolumn{1}{|c|}{ Treatments } & Kantedar $\left(\mathbf{V}_{\mathbf{1}}\right)$ & Allgreen $\left(\mathbf{V}_{\mathbf{2}}\right)$ & Mean \\
\hline 1. & Control $\left(\mathrm{T}_{0}\right)$ & 650.43 & 746.46 & 405.94 \\
\hline $\mathbf{2 .}$ & $\mathrm{GA}_{3} 50 \mathrm{ppm}\left(\mathrm{T}_{1}\right)$ & 980.31 & 973.32 & 976.81 \\
\hline 3. & $\mathrm{GA}_{3} 100 \mathrm{ppm}\left(\mathrm{T}_{2}\right)$ & 913.75 & 1015.68 & 964.71 \\
\hline $\mathbf{4 .}$ & IAA 50 ppm $\left(\mathrm{T}_{3}\right)$ & 843.44 & 840.39 & 841.91 \\
\hline $\mathbf{5 .}$ & IAA 100 ppm $\left(\mathrm{T}_{4}\right)$ & 796.70 & 999.58 & 898.14 \\
\hline $\mathbf{6 .}$ & TIBA 50 ppm $\left(\mathrm{T}_{5}\right)$ & 549.33 & 636.05 & 592.69 \\
\hline $\mathbf{7 .}$ & TIBA 100 ppm $\left(\mathrm{T}_{6}\right)$ & 813.59 & 588.59 & 701.09 \\
\hline & Mean & 792.50 & 828.58 & \\
\hline & & Variety & Treatments & V x T \\
\hline & SE $(\mathrm{D})$ & 6.72 & 12.57 & 17.79 \\
\hline & CD $(\mathrm{P}=0.05)$ & N.S. & 25.39 & 35.91 \\
\hline
\end{tabular}


Effect on seedling growth and vigour parameter

The state of good health and natural robustness in seeds, which upon planting permit rapid germination, normal growth and survival of the seedlings, produced under wide range of environmental condition. Seedling vigour is the sum total of all those properties in seed which upon planting result in rapid and uniform production of healthy seedling under wide range of environments including both favorable and stress condition (AOSA, 1975).The seedling vigour and growth-rate under field conditions indicate seeds vigour (Frank, 1950). Thus the collective properties of the non-dormant seeds determining the potential level of performance during germination and seedling emergence is expressed as seed vigour (Anon, 1995) which has indirect influence on final crop stand at harvest and yield.

Significant maximum root, shoot and seedling length and SV -1 was found when seeds were treated with 50 ppm $\mathrm{GA}_{3}$ (Hill et al., 2008, Patel et al., 2008) and showed values of 7.91 $\mathrm{cm}, 7.37 \mathrm{~cm}, 15.28 \mathrm{~cm}$ and 976.81 , respectively (Tables 3, 4, 5 and 7). But $\mathrm{GA}_{3} 100 \mathrm{ppm}$ and IAA 100 ppm also exhibited significantly similar performance to $\mathrm{GA}_{3} 50 \mathrm{ppm}$ for shoot length $(7.57$ and $6.99 \mathrm{~cm})$, root length $(7.35$ and $7.04 \mathrm{~cm})$ seedling length $(14.92$ and $14.03 \mathrm{~cm})$ and SV-1 (964.7 and 898.40). Growth regulator $\mathrm{GA}_{3} 100$ ppm exhibited significantly maximum seedling dry weight i.e., $0.570 \mathrm{~g}$ and followed by $\mathrm{GA}_{3} 50 \mathrm{ppm}(0.530 \mathrm{~g})$ and IAA100 ppm (0.520 g) (Table 6).

Significant detrimental effect of TIBA growth regulators with 50 and $100 \mathrm{ppm}$ was observed for shoot length, root length, seedling length and seedling dry weight as by above treatments the above parameters showed values significantly less than control (untreated).

Both concentration of TIBA i.e. 50 and 100 ppm significantly reduced the growth of seedlings in partially aged seeds of spinach and percent reductions over control were $35.22 \&$
14.84 for shoot length, 12.15 and 10.14 for root length, 24.70 nad 12.82 for seedling length and $16.00 \& 14.00$ for seedling dry weight with 50 and $100 \mathrm{ppm}$ concentration of TIBA, respectively. It is also cleared that $50 \mathrm{ppm}$ concentration of TIBA was more detrimental for seedling growth. These were supported by Singh et al., (2006) in Okra, Singh et al., (2006) in Okra, Bateshwar et al., (2008) in Okra, Hilli et al., (2008) in ridge gourd, Nabi et al., (2010) in okra, Rouhi et al., (2011) in soybean, Xu hui chun et al., (2013) in water melon, Mahipat et al., (2013) in mung bean, Vijendr kumar et al., (2014) in garden rue and Li Weifei (2014) in Robinia pseudoacacia.

Interaction effect of variety $\times$ treatments on seed germination, seedling growth and vigour

\section{Effect on normal and abnormal seedlings}

Partially aged variety Kantedar $\left(\mathrm{v}_{1}\right)$ of spinach showed significantly maximum normal seedling when treated with $50 \& 100$ ppm concentration of $\mathrm{GA}_{3}$ with values of 65.88 and $64.75 \%$ as well as minimum percentage of abnormal seedling was also appeared in interaction of variety Kantedar with 50 \& 100 ppm concentration of $\mathrm{GA}_{3}$ growth regulator with values of 19.27 and $20.07 \%$ whereas at par performance by variety Kantedar $\times$ IAA 100 ppm was also exhibited for minimum number of abnormal seedlings $(20.27 \%)$.

\section{Effect on seedling growth and vigour}

Variety Allgreen $\times \mathrm{GA}_{3} 100 \mathrm{ppm}\left(\mathrm{V}_{2} \mathrm{~T}_{2}\right)$ showed significantly higher shoot length $(7.65 \mathrm{~cm})$, root length $(8.33 \mathrm{~cm})$, seedling length $(15.98 \mathrm{~cm})$, seedling dry weight $(0.580 \mathrm{~g})$ and SVI-1 (1015.65). Similar finding was also found for variety Garima of soybean (Mahipat et al., 2013). Variety Kantedar with $\mathrm{GA}_{3} 100$ ppm $\left(\mathrm{V}_{1} \mathrm{~T}_{2}\right)$ also showed at par performance to Allgreen $\times \mathrm{GA}_{3} 100 \mathrm{ppm}\left(\mathrm{V}_{2} \mathrm{~T}_{2}\right)$ for shoot length $(7.49 \mathrm{~cm})$ and seedling dry weight $(0.570 \mathrm{~g})$. Variety Allgreen $\times$ IAA $100 \mathrm{ppm}$ $\left(\mathrm{V}_{2} \mathrm{~T}_{4}\right)$ showed significantly higher values for 
shoot length $(7.73 \mathrm{~cm})$ seedling length $(15.67$ $\mathrm{cm})$, root length $(7.94 \mathrm{~cm})$ and SV-1 (999.58) and at par to best performance.

Kantedar variety $\left(\mathrm{V}_{1}\right)$ when interacted with growth regulator IAA $100 \mathrm{ppm}$ concentration $\left(\mathrm{T}_{4}\right)$ showed better performance for abnormal seedlings (20.27\%) and similar performance to the best.

\section{References}

Bateshwar, Priyanka Kumar and Gaurav, S. S. (2008). Effect of growth stimulants on seed germination and vigour index in okra (Abelmoschus esculentus L.). Progressive Res.3 (2): 195-196.

Hilli, J. S., Vyakarnahal, B. S. and Biradar, D. P. (2008). Influence of growth regulators and stages of spray on seed quality of ridge gourd(Luffa acutangula L. Roxb). Karnataka J. of Agril. Sci. 21 (2): 194197.

Li WeiFEI (2014). Effect of plant growth regulators on seed germination of Robinia pseudoacacia. Guizhou Agril. Sci..42(4): 100-103.

Nabi, Ambreen; Sharma, S. K. and Shukla, Y. R. (2010). Influence of plant growth regulators on seed yield and quality of okra. Annals of Agri Bio Res. 15 (1) 21-23

Natesh, N; Vyakaranahal, B. S.; Gouda, M. S. and deshpande, V. K. (2005). Influence of growth regulators on growth, seed yield and quality of Chilli cv. Byasagi Kaddi. Agril. Sci., 18(1): 36-38.

Nirmala, K. and Umarani, R. (2008). Evaluation of seed priming methods to improve seed vigour of okra (Abelmoschus esculentus) and beetroot (Beta vulgaris). Seed Sci. and Tech., 36(1): 56-65.
Patil, D. R. and Patel, M. N. (2010). Effect of seed treatment with GA3 and NAA on growth and yield of okra (Abmelmoschus esculentus L. Moench) cv. GO-2. Asian J. of Hort., 5 (2): 269-272.

Rouhi, H. R.; Surki, A. A.; Sharif-Zadeh, F.; Afshari, R. T.; Aboutalebian, M. A. and Ahmad, V. G. (2011). Study of different priming treatments on germination traits of soybean seed lots. Notulae Scientia Biologicae, 3 (1): 101-108.

Singh, Jaswinder; Kanwar, J. S. and Bassi, Geeta (2004). Seed vigour as influenced by different seed priming treatments in okra (Abelmoschus esculentus L.Moench). Seed Res. 32 (2): 122-125

Singh, Poonam; Singh, V.; Maurya, C. L.; Swarnkar, S. K. and Bajpai, V. P. (2006). Selection of suitable growth regulator and spacing for seed yield and quality of okra (Abelmoschus esculentus L. Moench) cv. KS-404. Seed Res. 34 (1): 61- 65

Thapa, U.; Das, R.; Mandal, A. R. and Debanath, S. (2013). Effect of $\mathrm{GA}_{3}$ and NAA on grow yield and quality character of sprouting broccoli (Brassica oleracea). J. Crop Science Hissar 46(1): 192-195.

Vijendra Kumar; R. C. Sreeramu; B. S. Halesh and G. K.(2014). Effect of pre- sowing growth regulator treatments on germination and seedling growth of garden rue (Ruta graveolens Linn.). Asian J.of. Hort., 9 (1):193-197.

$\mathrm{Xu}$ HuiChun; Wang Di ZhiQiang; Hu XiXi; Zhang HongYU; Xu Lei; Li ZhiXue and HanMo (2013). Effect of plant growth regulator on germination and seedling growth of seedless watermelon. $\mathrm{J}$ of China cucurbits and vegetables. 26 (4): $37-40$.

\section{How to cite this article:}

Satya Prakash, Poonam Singh, Kunwar A.P. Singh, Vipul Singh, Raghvendra Singh, S.C. Vimal and Sagar Kumar Sharma. 2017. Effect of Plant Growth Regulators on Partially Aged Seeds of Spinach (Spinacea oleracea L.) Genotypes. Int.J.Curr.Microbiol.App.Sci. 6(11): 1327-1334. doi: https://doi.org/10.20546/ijcmas.2017.611.159 